\title{
The Current Status of Social Work Science and Research: A Review of the Literature and Its Implications for Post-Soviet Countries
}

\author{
Shorena Sadzaglishvili, PhD, MSW \\ Associate Professor \\ Ilia State University, 3-5 Cholokashvili Street, 0162 Tbilisi, Georgia \\ Tel: $+(995)$ 577-501-577 \\ E-mail: shorena_sadzaglishvili@iliauni.edu.ge; ss2051@columbia.edu
}

Received: May 7, 2017 Accepted: May 23, 2017 Published: May 24, 2017

doi:10.5296/ijsw.v4i1.11157ＵRL: http://doi.org/10.5296/ijsw.v4i1.11157

\begin{abstract}
This paper offers a review of the major literature about the modern status of social work as a science within the American and European contexts and its implications for post-Soviet countries where social work is an emerging profession. It identifies the most appropriate types of social work research (e.g. translational research) that can be used for bridging the science and service communities to directly affect the provision of services across different social work sectors. It also provides historical analysis of the various organizations within European and American social work to show their pivotal role in improving the scope and quality of social work research and consequently, social work as a science. And finally it suggests ways of increasing visibility of social work as science in post-Soviet countries through development of sound social work doctoral programs.
\end{abstract}

Keywords: Social work education, Social work science, Social work research, Post-Soviet countries, Doctoral education in social work, Translational research, Social work profession

\section{Introduction}

One of the strengths of a profession depends on its empirically derived knowledge base as it informs its practice and empowers practitioners through research. As a result of its venerable history, Social Work still struggles with its professional identity, remaining sensitive to the allegation that it lacks a unique subject matter or methodology, which creates a void in creating evidence based practices. Moreover, social work as 'a science'

is not emphasized in its mission statements in National Association of Social Workers (NASW), Council on Social Work Education (CSWE), International Association of Schools of Social 


\section{Macrothink}

Work (IASSW) and International Federation of Social Workers (IFSW). Thus, the conceptual context of 'social work as a science' from which social work educators can design and deliver solid well-structured evidence based social work educational programs is missing.

This paper offers a review of the major literature about the modern status of social work as a science within the American and European contexts and its implications for post-Soviet countries where social work is an emerging profession. It identifies the most appropriate types of social work research (e.g. translational research) that can be used for bridging the science and service communities to directly affect the provision of services across different social work sectors. It also provides historical analysis of the various organizations within European and American social work to show their pivotal role in improving the scope and quality of social work research and consequently, social work as a science. And finally it suggests ways of increasing visibility of social work as science in post-Soviet countries through development of sound social work doctoral programs.

\section{Social Work as an Integrative Scientific Discipline}

While Social Work education has historically been grounded in professional practice, reconsideration of Social Work as a science has recently been urged (Fong, 2012). American and European colleagues initiated discussion about increasing Social Work's visibility as a scientific discipline and making a more demonstrative contribution to expanding the scientific knowledge base in social and human services (Anastas, 2014; Shaw, 2014; Sommerfeld, 2014; Brekke, 2012, 2013; Marsh, 2012; Longhofer \& Floersch, 2012).

One indicator of Social Work lacking scientific shape is that social workers have not contributed towards the scientific advances and evidence based treatments as much as other professionals such as psychologists, psychiatrists, public health, and sociologists. For instance, to take into consideration the total number of social work journals and the impact factors of these journals indicate that social work's contribution to the expanding social science knowledge base has been relatively restricted (Brekke, 2012).

Other limitations are that social work textbooks and journals exemplify the piggyback approach', embracing knowledge from any discipline relevant to the topic at hand. As Brekke (2012) observed, this interferes with Social Work defining itself as a social science. The Social Work professional mission statements, codes of ethics and accreditation documents lack references to itself as a 'science' (Fong, 2014; Brekke, 2012; Marsh, 2012). According to Brekke (2012) in the most recent version of the Code of Ethics of the National Association of Social Workers (2008), science is not mentioned and the word 'research' appears only once toward the end of the second paragraph. Moreover, the Council of Social Work Education's (CSWE) mission statements and accreditation requirements identify Social Work professionals as practitioners (Fong, 2013).

According to Whitaker, Weissmuller and Clark, (2006) study of licensed social workers in the United States, a majority were involved in direct practice and only $58 \%$ of licensed social workers with doctoral degrees self-reported doing some research, although the nature of this work was not described. There is little evidence that practitioners see themselves as scientific (Anastas, 2014). Moreover, employment statistics show a significant presence of social workers in health, mental health and human service positions, whereas social work researchers 
account for less than $1 \%$ of all researchers actively involved in federally funded projects (Bureau of Labor Statistics, 2012).

The gap between science and practice has long been noted in the literature (Backer et al., 1995; Morrissey et al., 1997; Clancy \& Cronin, 2005). Moreover, Brekke et al. describe several American reports showing a 20-year gap between knowledge generated from the best clinical research and utilization of that knowledge in health and mental health sectors (Brekke, Ell, \& Palinkas, 2007).

Yet, there is also an impetus in evidence-based practice for practitioners and researchers to collaborate in establishing research priorities, developing appropriate methodologies and producing useful and relevant research findings (Plath, 2006). This trend towards increased practitioner/researcher alliances has been observed in both Britain and the United States (Cheetham, 1997; Mullen, 2002; Webb, 2002). One way to minimize the gap between research and practice is to develop a 'translational' science that will speed up the use of findings from the evidence based best science practice into direct care settings, while building partnerships between research and practice constituencies (Brekke, Ell, \& Pelinkas, 2007).

In this context, Marsh (2012) argues that it is very relevant to ask whether a particular study has markers consistent with Social Work's core constructs, professional purpose and ethical code, or whether it is derived knowledge from psychology, psychiatry, public health, sociology or other related fields. Analyses that ask whether a piece of research is consistent with the core constructs, values and fundamental purposes of Social Work are critically important to advancing the scientific base of social work practice and establishing more clearly the identity of the profession (Marsh, 2012). Guerrero (2014) asserts that the situational context offers more opportunities than challenges for Social Work to become a scientific enterprise. The current framing of major social problems, he says, is consistent with the profession's main concerns about contextual factors having a critical role in realization of individual's full potential. Thus, Social Work is well situated to lead conceptual and methodological discussions of client-centered and community based approaches among vulnerable populations (Guerrero, 2014).

Social Work along with sociology, psychiatry, public health, psychology is an applied integrative science, not a natural or core science that engages in the development of knowledge for its own sake (Anastas, 2014). According to the International Federation of Social Workers (IFSW) and International Association of Schools of Social Work (IASSW), Social Work is both interdisciplinary (several disciplines working jointly from their discipline-specific bases to integrate, combine, or synthesize perspectives, concepts, and/or theories to address a common problem) and transdisciplinary (a collaboration between several academic disciplines and practitioners in professional fields outside academe to address a complex real-world problem). In contrast to the core or natural scientific disciplines (such as biology, chemistry, etc.), the integrative scientific disciplines seek to push disciplinary boundaries for solving 'problems in living' (Brekke, 2013, p. 522). They are defined by their explicit focus on the application of disciplinary knowledge in integrative ways. Thus, their knowledge is always applied and technological (Brekke, 2013). Social work as an integrative applied discipline provides new applications of existing theories (from social sciences and humanities) to problems in life and develops new social work integrative 
theories, 'indigenous knowledges' (IFSW) and models and guides in solving critical social work problems, which can be replicated.

Sommerfeld (2014) defines social work as an 'action science' which means that it is constituted by the real life problems of social work practice and it is also 'transdisciplinary' as it is building a consolidated knowledge base of social work where the main challenge consists of integrating multidisciplinary knowledge in a transdisciplinary way. This approach of action science goes beyond evidence-based practice. It does not evolve from adding and meta-analyzing empirical data rather than it composes specific theories of action so called 'technological knowledge' comprising of multidisciplinary knowledge (Sommerfeld, 2014). Action theories are theories of special kind. They are theories on the relation between ends and means, theories of rational target-oriented action and it meets four criteria: (1) they are based on verified theories that explain the causal factors that lead to the emergence of a problem of a concern in a field of practice; (2) the treatment has to be described and there has to be at least plausibility that this treatment affects the causal factors; (3) a scientific explanation of how treatment affects the causal factors - how the treatment works - is developed and (4) the treatment has been proven effective (Sommerfield 2014). The aim of transdisciplinary action science of social work is to enable the profession and professional practitioners to make responsible and informed choices that would become a solid ground for legitimacy of professional social work. In addition, the knowledge produced in practice has to be integrated as well (Sommerfeld, 2014).

A critical task is to distinguish social work from other integrative scientific disciplines. Social work is the only helping profession that explicitly promotes social change and the social justice (Payne, 2006). In fact, the international definition of social work (IFSW, 2014) claims that social justice is fundamental to it. Accordingly, social work has three functions: (1) therapeutic, which may promote change on an individual bases; (2) problem solving in human relationships, promoting interpersonal and social 'harmony' and (3) promoting social development and/or social change (Adams, Dominelli, \& Payne, 2009, p. 2).

Brekke $(2012$, 2013) defines the framework of the science of social work with (a) core constructs (biopsychosocial, person-in-environment and service systems for change), (b) core domains (1. to understand: marginalization, disenfranchisement, the individual and social factors in disease and individual and social factors supporting health and (2. to foster change: empowerment, inclusion, reducing disease, and increasing health), and (c) aesthetic characteristics (complexity, synthesis and pluralism). In addition to this, a science of social work must encompass the issues relevant to an evidence-based approach to social work practice (Brekke, 2012) as evidence based practice (EBP) is the area where social work has an explicit relationship with science. In particular, EBP provides science informed practice (so called the scientific practitioner - Rosen, 1996) and it also includes development and implementation of evidence based or evidence supported practice interventions (e.g. problem solving therapy; assertive community treatment and etc.). Thus, EBP can be seen as a central feature for a scientific, accountable, informed and ethical approach to social work practice (Brekke, 2012).

\section{The Characteristics of Social Work Research}

Social work's commitment to rigorous research is the major indicator for defining social work 
as a science. According to both Action Network for Social Work Education and Research (ANSWER); National Association of Social Workers [NASW], 2015, 'social work research benefits consumers, practitioners, policy-makers, educators, and the general public through the examination of societal issues such as health care, substance abuse, and community violence; family issues, including child welfare and aging; well-being and resiliency; and the strengths and needs of underserved populations. Social work research identifies strategies and solutions that enhance individual, family and community well-being by exploring the social, behavioral, and environmental connections to health and mental health issues, and examines the inter-relationships among individuals, families, neighborhoods, and social institutions by conducting research in schools, communities, health care facilities, and human service agencies.' Social work research provides empirical support for best practice approaches to improve service delivery and public policies (NASW, 2015).

In 1988 the task force on Social Work research consisting of 13-members appointed and funded by NIMH and it developed a 108 page report entitled 'Building Social Work Knowledge for Effective Services and Policies'. This report consists of six sections beginning with a discussion of the 'crisis' in social work research and moving through research education, research productivity and research careers, research dissemination and utilization, support systems for research, and a plan for research development. Conclusions from this report is valuable as it helps others who view social work as a profession demonstrates that social work has a significant and important research dimension. In particular, this report advocates for more government funding, it calls for more research training for social work students with an emphasis on utilization and proficiency in methods and analytic techniques, and it advocates for strengthening accreditation standards pertaining to research and the integration of research and practice (National Advisory Mental Health Council, 1991).

In the past two decades historic improvements in the scope and quality of social work research and research capacity have been made through enormous investments by federal entities such as the National Institutes of Health (NIH), the Institute for the Advancement of Social Work Research (ASWR), and concentrated efforts by deans, directors, and faculty members. All of these have led to important advances in research infrastructure and capacity in many social work programs (Jenson, Briar-Lawson, \& Flanzer, 2008).

In 2009, at the 13th Annual Meeting of the Society for Social Work and Research (SSWR), the quality and quantity of social work was still criticized. Some scholars mentioned that 'social work students, faculty, and the intellectual leaders of the profession (that is, editors, reviewers, and deans) are ill-prepared for the intellectual rigors of professional scholarship' (Howard, 2009, p. 4). In fact, there are indications of growth in the quantity and quality of social work research; however, serious systemic issues currently limit the production, utilization, and utility of social work research (Howard, 2010).

Social work leaders have long debated the particular patterns of how social work researchers pursue scientific inquiry (Guerrero, 2013). The general concern was the extent to which social work has adopted a methodological rather than substantive approach to conducting research (Brunswick Heineman, 1981).

According to Tripodi and Potocky-Tripodi (2005), social work research is defined as the use of social research methods (e.g., qualitative research, participatory research, ethnographic 
field studies, case studies, needs assessments, program evaluations, single-subject designs, participant and nonparticipant observation, secondary data analyses, experiments, quasi experiments, surveys, etc.) for producing and disseminating knowledge (hypothetical, qualitative-descriptive, quantitative descriptive, associational or correlational, causal) that is pertinent to policies and practices that affect and/or are implemented by social work organizations, practitioners, administrators, and educators. The research methods employed depend on the level of knowledge sought, financial and ethical considerations, the sociopolitical environment, and expertise in the use of research methods (Tripodi, 2005).

There are some authors who consider social work research in different context as the social work profession has its unique ethical values as it emphasizes human rights and human dignity, a commitment to serving marginalized and oppressed people, and a mission to foster a more just society (Witkin, 1995). This ethical context is augmenting the value of social work research. In comparison with other helping professions, social work claims to embrace a very distinctive mission: to oppose the roots and effects of social oppression. Thus, social work research is considered as anti-oppressive research and it should be assessed from an anti-oppressive social work perspective (Strier, 2007). Strier (2007) argues that in order to match the liberating mission of the profession, social work research should defy the dominant traditions of social science research.

DePoy, Hartman and Haslet (1999) suggest a critical action research model as a framework for social work inquiry that is consistent with the mission, values, and aims of the profession. Philosophical foundations of this model is purposive, inclusive, empowering, and action oriented. Moreover, in concert with the contemporary trends for accountability and evidence-based practice, action orientation using this model is well informed by sound and participatory inquiry. This model provides a bridge between the university and the community and between research and practice. Although implementing such a model is a complex process, the critical action model provides systematic guidance through which multiple groups can assume a critical approach to knowledge that informs the development and implementation of social and human services. Action research can use action processes from either experimental and naturalistic traditions or an integration of the two. However, consistent with its principles, all research occurs within its natural context, and it relies on strategies that characteristically are interpretive in nature (DePoy, Hartman, \& Haslet, 1999).

Proctor (2003) proposes so called intervention research as the most relevant for social workers. Moreover, social work researchers are encouraged to conduct not only intervention research, but also intervention informative research. In particular, research about practice, its challenges, its priorities, and its participants, has the potential to inform intervention development and guide the application of existing interventions to new practice contexts. Thus, research needs to help us better understand problem severity, duration, variability over time, costs, and consequences for social and interpersonal functioning. Also important are clinical epidemiological studies that document problem prevalence among the clients served by social services agencies as they can inform treatment priorities and assessment protocols (Proctor, 2003).

Social work needs to make a greater investment in producing scientific knowledge to enable community change (Coulton, 2005). Social work research agendas should have more rigorous 


\section{Macrothink}

International Journal of Social Work

ISSN 2332-7278

2017, Vol. 4, No. 1

research designs, drawing on matching, time series, and other principals of experimentation (Coulton, 2005). The use of statistical analyses to examine community influences should be multilevel, and spatial statistics should be incorporated into community intervention studies. For this reason more systematic and comparable methods of documenting community interventions and boundaries should be engaged (Coulton, 2005). Moreover, social work needs to invest in ecometrics, not just psychometrics Unick and Stone (2010). Unick and Stone (2010) also indicate the importance of employing more complicated measurement procedures for social work research. In particular, they focuses on IRT (Item Response Theory) modeling as it provides greater capacity for understanding and accounting for measurement bias across diverse populations.

Recent trends in social work research development shows more focus on interdisciplinary and collaborative research. NIH aims at advancing social work research through four types of social work investigations: (1) studies that assess the effectiveness of existing social work services and interventions on health outcomes; (2) investigations to develop and test the effects of innovative social work interventions on client functioning; (3) proposals that aim to improve health outcomes through interventions delivered in nontraditional health care settings; and (4) studies that examine effective program implementation strategies in communities (Jenson, 2006, 2008). Thus, Creating and sustaining interdisciplinary research is a significant challenge in the larger context of infrastructure and research capacity which translates into competitive grant awards are increasingly inter- or multidisciplinary (Jenson, 2008), Building investigative teams across disciplines occurs more quickly in a school or department culture that values input and scholarly contributions from other disciplines (Jenson, Briar-Lawson, \& Flanzer, 2008).

In response to interdisciplinary and collaborative research, the authors also offer a set of strategies for building and sustaining research collaborations between university and community-based social work professionals (Begun et al., 2010). Social work researchers, social work educators, and social work practitioners should engage in collaborative partnerships that improve social work practice through research and advance the knowledge base of the profession (Begun et al, 2010). Community-based participatory research (CBPR) is an emerging methodology for bridging gaps between research knowledge production and community-based practices (Ahmed, Beck, Maurana, \& Newton, 2004; Currie et al., 2005; Jason, Pokornyji, \& Kunz, 2005; O’Fallon \& Dearry, 2002; Viswanathan et al., 2004).

Finally, the notion of importance of building a translational science agenda in social work research became very actual issue (Brekke, Ell, \& Palinkas, 2007; Fong, 2012). Translational science takes both research informing practice competency and the practice informing research competency and operationalizes them to tie the researcher and the practitioner more closely together (Fong, 2012). There is a great need for translational research in mental health services for children and adults, schools, corrections, child welfare, and services for elderly (Brekke, Ell, \& Palinkas, 2007). The goal of translational science is to support research that will build the models and methods needed to bridge the science and service communities, and thereby directly affect the provision of services in all of these usual care settings across sectors and populations. In this regard, NIMH prioritizes two goals for social work research: (1) to speed the use of promising and evidence based mental health practices into usual-care 


\section{N Macrothink}

International Journal of Social Work

ISSN 2332-7278

2017, Vol. 4, No. 1

settings and (2) to train service researchers to develop and participate in interdisciplinary investigative teams (Brekke, Ell \& Palinkas, 2007). Thus, practice-based research or critical action research, intervention research and community based participatory research (so called translational research: a new horizon for social work research by Nurius, Brekke \& Fong, 2010) share an overarching theoretical framework and can be considered as the most appropriate types of social work research.

\section{Institutional Response to Development of a Profession and Science of Social Work in the United States and Some European Countries}

The formation of the International Association of Schools of Social Work (IASSW) and the International Federation of Social Work (IFSW) in 1928 and 1929, respectively, gave impetus to the profession in organizing practitioners and educators from around the globe (Estes, 2009). These two international organizations have also provided leadership in connecting international development organizations worldwide. In 2013, IFSW and IASSW proposed a new definition of Social Work, including how it 'draws on a wide array of scientific theories'. As Anastas (2014) points out, 'science' is here understood as the development of 'knowledge'. For advancement of social work as a science in the United States, there were four major social work organizations that were created, Group of Advancement of Doctoral Education in social work (GADE) in the late 1970s; Institute for the Advancement of Social Work Research in 1993; Society for Social Work and Research (SSWR) in 1994, and ANSWER (Action Network for Social Work Education and Research) in 1995. In 1992, GADE published guidelines emphasizing research scholarship in doctoral education. Social work research activities were strengthened by the introduction of research infrastructure development grants by NIMH from 1993 to 2000 and by NIDA from 2000 to 2003. In the same period, SSWR started awarding annual research prizes (Barth et al, 2014). GADE revised its Quality Guidelines for PhD Programs in Social Work (Fong, 2013). In their revised version of 'Quality guidelines for PhD programs in social work'. GADE Taskforce on Quality Guidelines the science of social work is mentioned (Harrington, Petr, Black, \& Cunnigham-Williams, 2013). In 2009 the American Academy of Social Work and Social Welfare (AASWSW) was established with the support of major (NASW and CSWE) social work organizations, who's aims is recognizing outstanding social work scholars and practitioners. At the same time informing social policy by serving as a signal scientific source of information for the social work profession and agencies. It also promoted the examination of social policy and the application of research to the design and development of more effective public policies, social welfare programs, and social work practice; and celebrating excellence in research, education, and practice (Barth et al, 2014). However, in order to strengthen the scientific status of social work it is suggested to revise the mission statements of NASW and CSWE so they reflect qualities that are crucial to the science of social work such as: (1) scientific inquiry, (2) transdisciplinary scope, (3) scientific methodology, (4) evidence-based practice, and (5) translational science (Fong, 2012). Issues of social work research not being introduced as science in the United States where schools of social work at universities have had long traditions of teaching research and demanding research from its professors to acquire tenure is well documented. But the conflict of social work research not being grounded in science is still an issue.

On the other hand, looking at social work's position in Europe we find the status of social work 
can be described as poor and struggling for acknowledgement (Sommerfeld, 2014, Erath \& Littlechild, 2010). Despite the different approaches of the European nations towards social work (e.g. English social work highlights 'accountability' and 'evidence'; German social work underlines notion of 'social justice'; Czech and Slovakian social work rely on consistent identification of the occupational group, similar to Sweden, Finland and Norway) nothing has considerably contributed to an improvement of the status of social work in the European countries (Erath \& Littlechild, 2010).

However, social work holds stronger position in those countries in which it has developed comprehensively both theoretically and practically. In the Nordic countries where social work has a less stronger positions in those countries in which social work is merely understood as a practice (e.g. in the United Kingdom, France). But in the Czech Republic and Slovakia, social work is only seen as a science. In Germany, Austria, and Switzerland, social work does not have a strong position as a science nor as a practice.

In 1996, Social Work Education sponsored by the Council of Europe concluded that in the context of significant changes in education and training for social work, 'social work research seems underdeveloped in Europe' (Council of Europe, 1996, p. 25). This deficit encouraged the European Union to fund a French Initiative (from 1997 to 2000) aimed at 'mapping' the state of doctoral work within and beyond EU countries (Laot, 2000). Results from that mapping showed that French research lack knowledge in Europe about social work doctoral studies. European experiences contrasted sharply with the doctoral programs and doctoral thesis in the USA (Lyons, 2010).

Social work researchers in the US are focused more on quantitative and positivistic approaches than their European colleagues (Garvin, 2010). However, the differences of social work doctoral programs and research paradigms between countries within Europe were also very significant and reflected the stages of development from the discipline of social work in each European country. In addition, there were also other significant factors identified such as the wider welfare contexts and national educational traditions that made comparative study a very complex activity (Lyons, 2010).

The UK's largest organization Economic and Social Research Council (ESRC) for funding research on economic and social issues funded the seminar series 'Theorizing Social Work Research' to foster social work doctoral education and research and to raise the profile of social work as a research-based discipline (ESRC Report, 2000). Following its UK colleagues, the Swiss Society of Social Work (SSSW) founded in 2006 contributed to the development of the social work science by organizing debate and representing the discipline in political, educational, and scientific organizations. In 2013, the delegates of the Swiss Academy of Humanities and Social Sciences unanimously elected to SSSW a new member of the Academy after having thoroughly evaluated the scientific performance of Swiss Social Work Science over the last 10 years (Sommerfeld, 2014). Despite the differences, European social workers emphasize the multi- or inter-disciplinary nature of social work (Dellgran \& Hojer, 2000; ESRC Report, 2000). In addition, it is indicated that the choice of methodology must relate to the purpose of the research either aimed at informing policy and practice developments or at challenging conventional assumptions and exploring new ideas for creating knowledge in social work and the social sciences (Lyons, 2010). As a matter of fact, the European social 
work research lacks problem-oriented basic research in which issues of academic literature are developed and tested empirically as the respective national practices of social work are weak to address such fundamental questions (Erath \& Littlechild, 2010).

To summarize, formation of the major social work research lobbing organizations, funding from the largest research and academic organizations and their institutional investments played a key role for improvement the scope and quality of social work research, research capacity and infrastructure in many social work programs in the United States as well as in the Europe.

\section{Increasing Visibility of Social Work as Science in Post-Soviet Countries: Discussion}

Post-Soviet countries included fifteen former Soviet Socialist republics which shared the same "soviet regime" past related to their social-economic and political development despite their differences. In particular, the soviet regime was based on a social contract between workers and politicians, which guaranteed "a secure, social and economic existence to workers", and they, in turn, "left politics to the politicians" (Cook, 1994, p. 7). The economy of the Soviet Union differed significantly from market economies as "the country's economic resources were extensively owned by the state" (Federal Research Division, 1989, p. 2).

The soviet welfare system approach was "institutional" and it was considered as "an ongoing, comprehensive social institution" whose major function was to prevent social breakdown and to make available "assistance" as a right. Massive social protection systems were run and implemented solely by the state. Soviet welfare planners believed that a high level of economic security and a healthy concern of the state for the welfare of its citizens are essential for maximum production (Madison, 1968, p. 8).

The Soviet Union preferred not to create a new profession to meet certain human needs, but rather to assign welfare functions to educational and health personnel who were generally better established and understood (Madison, 1968). Thus, Social work as a profession did not exist in the Soviet Union. Welfare functions were performed by various persons with different backgrounds and types of academic preparation. These not only included the untrained worker, but attorneys, public health nurses, children's inspectors with special secondary education.

In the soviet welfare system, the relationship between the welfare personnel (worker) and the individual were based on "social humanism" ideas, which underlined that a "constructive relationship" would result almost automatically if the welfare worker demonstrates genuine interest, respect, and sympathy. In short, welfare personnel adopted rationally learned behavior based on a rational common-sense attitude while in dealing with their consumers. They did not practice into "deeper" causes, into the emotional quality of interpersonal relationships, as social work was presented in the Western countries (Madison, 1968). One of the most important and widely used therapies carried out by the welfare personnel was "Work Therapy". Based on the Soviet emphasis on the rational rather than the instinctual elements of behavior, "Work Therapy" became the ultimate in the "Theory of the Unity of Consciousness and Activity" in contrast to Strength/ Empowerment Perspective, Social Justice/Human Rights Approach, Human Behavior in the Social Environment/Person in the Environment and Ecosystems Perspective (Madison, 1968, p. 3).

The Soviet welfare and health care system suffered from "as many of the ills as the rest of 


\section{MInstitute Macrothink $_{\text {Int }}$}

Soviet society, such as low work incentive, poor productivity, corruption and elitism" (Fridenberg, 1987, p. 214). One of "the most harmful, costly, and intractable legacies" of the command economy of the former Soviet Union was the reliance on residential institutions for the care of children, the elderly, and people with disabilities (Tobis, 2000, p. 2). As a result, there were almost no community-based alternatives to care for large and growing numbers of vulnerable individuals. Poor, neglected, or disabled children lived in institutions that adversely affected their physical, emotional, and intellectual development. Children with disabilities were segregated from society and kept in harsh conditions. The elderly and disabled adults were cloistered in social care homes. However, the Soviet system did not recognize harmful effects of institutional care on the process of human development. Moreover, historically throughout the former Soviet bloc, persons with physical and mental disabilities have been "stigmatized, hidden from the public, and thus made seemingly invisible" (S. P. Dunn \& E. Dunn, 1989).

After its collapse in 1991, individual countries of the Soviet Union moved from having a tradition of "no social problems" towards facing major social and economic challenges (IFSW, 2014). These macro-level "large scale ecological changes" from a communist utopian social-economic system to a market oriented one, from a federated central government to individual national (and potentially democratic) governments, and from collectivist responsibility towards individual responsibility, instigated changes at meso- and micro-levels. The post-Soviet states have gone through multiple reformation processes at all levels of social life including the dramatic reconstructing of their economic, political, and welfare systems. Such transformation has created opportunity for social work as a new profession responsible for dealing with the prevailing social needs of its citizens (An, 2014). Instigated by the common social-economic and human crisis, the common social problems are poverty, unemployment, institutionalization and violation of children's rights and human rights, trafficking and violence, the growth of crime, drug abuse, deterioration of health, suicide, social exclusion of disabled and minorities, and etc. As An (2014) summarized the development of social work is an integral component of social policy reform in post-Soviet countries. Consequently, the priority task became preparation of a social work force through university and academic education. As a result, Bachelor, Master and, rarely Doctoral programs were established to prepare professionals in Social Work. However, the new profession of Social Work is significantly challenged within academia, as it is not seen as a scientific and research field and sometimes, is seen as a vocation and "secondary" profession. The consequent lack of qualified social work practice and policy researchers, as afforded in the research university setting, prevents internal and comparative research, as well as the delineation of best social work practices at micro and macro levels, and the production of adequate professional manpower.

Thus, social work is not a well-established academic field in the former Soviet Union countries. Moreover, analysis of social work development internationally shows that the social work practice has developed disparately in the context of separate nation states and it is idiosyncratic to the concrete cultures and countries (Penna, Paylor, \& Washington, 2000). In particular, social work is still lacking scientific shape and there is a need for clear definition of social work as an integrative scientific discipline and its research methodology. "Social 
Work Research" itself is not clearly and coherently identified by well-known American and European social work scholars. Thus, it is critical to promote an idea of Social Work as Science worldwide and especially, in the countries where social work is a newly emerging discipline. In this case, social work will be raised as a global profession, "super national" and scientific field concerned with global issues (e.g. as refuges, poverty, public health, violence, disability, children separated from the families and etc.) and will meet ongoing globalization discourse and global political and economic processes (Penna, Paylor, \& Washington, 2000). At the same time, Scientific Social Work will be able to answer national challenges considering its ecological contexts based on evidence based practices and scientific innovations to shape effective and responsive social policy and intervention programs in transitional countries.

As historical analysis of social work development showed one direct way of promoting social work as a science is to establish sound doctoral programs in research university settings (Reid, 2011). These programs should highlight the importance of academic research and not sacrifice 'gold standards' for doctoral education in social work in the context where social work is considered as a vocational and practical profession and social work doctoral graduates are not accepted as 'true' scientists among scientific communities. Sound doctoral education in social work should focus on teaching qualitative as well as on quantitative and positivistic approaches and comprehensive research methodologies to identify and study meaningful topics and social problems.

Doctoral students need to become scholars within the academy, which means that they should be required to take courses that make social work distinctive in the $\mathrm{PhD}$ program along the lines of Social Justice and Human Behavior in the Social Environment (Fong, 2013). It is important to highlight intersectionality and a transdisciplinary approach for faculty who are teaching courses for doctoral students. This approach expands the scope of learning and mitigates the dichotomy between basic and applied research (Fong, 2013). Thus, doctoral education needs multiple mentors from different disciplines to understand and use a multidisciplinary approach and doctoral programs should incorporate team-taught courses presenting a multidisciplinary framework (Fong, 2012). For instance, a best practice is designing multi-professional teaching clinics, bringing together expertise from different social sciences/disciplines, e.g. psychology, public health, mental health, social policy to advancing solutions to difficult social issues in the region.

In combination with establishing sound doctoral programs in Social Work it is necessary to form social work Research Lobbing Organizations and Funding Institutions that will support building a research infrastructure for Schools of Social Work and advance "Social Work Research" opportunities.

Finally, Schools of Social Work should implement Translational Research as an advanced social work research modality that will open up ways of dialogue and collaboration between university and community. Consequently, social work will gain stronger position among other well-developed scientific disciplines by promoting its theoretical and practice basis comprehensively. Translational Research opportunities in the transitional contexts of the post-Soviet countries will have a positive affect on dissemination practices of social 


\section{Macrothink}

International Journal of Social Work

ISSN 2332-7278

2017, Vol. 4, No. 1

interventions by facilitating evidence-based, sustainable solutions to emerging public health and social challenges.

\section{Acknowledgment}

This paper would not have been possible without the generous support of my mentors, colleagues, and family. As a Fulbright scholar of 2014-15 (under grant ID 68141013) I met with my American colleagues from New York University, Silver School of Social Work and discussed many aspects of social work as a science where they shared their insights. I am grateful for their constant support during my fellowship. Also, I would like to acknowledge the staff at the Center for Latino Adolescent and Family Health where I spent my best days.

\section{References}

Adams, R., Dominelli, L., \& Payne, M. (Eds.). (2009). Social work: Themes, issues and critical debates (3rd ed.). Basingstoke, United Kingdom: Palgrave Macmillan. https://doi.org/10.1007/978-1-137-08215-2

Ahmed, S. M., Beck, B., Maurana, C. A. \& Newton, G. (2004). Overcoming barriers to effective community based participatory research in US medical schools. Education for Health, 17(2), 141-151. https://doi.org/10.1080/13576280410001710969

An, S. (2014). Social work between "Westernization" and "nationalization": The transnational perspective on social work in post-socialist/post-Soviet states. In C. Bahr, H. G., Homfeld, C. Schröder, W. Schroer, \& C. Schweppe (Eds.), The World Atlas of Social Work. Weinheim/München: BELTZ Juventa.

Anastas, J. W. (2014). The science if social work and its relationship to social work practice.

Research on Social Wractice, 24(5), 571-580. https://doi.org/10.1177/1049731513511335

Backer, T. E., David, S. L., \& Soucy, G. (1995). Introduction. In T. E. Backer, S. L. David, \& G. Soucy (Eds.), Reviewing the behavioral science knowledge base on technology transfer (Vol. 155, pp. 147-168). Rockville, MD: National Institute on Drug Abuse. https://doi.org/10.1515/9781400863983.ix

Barth, R. P., Gilmore, G. C., Flynn, M. S. Fraser, M. W., \& Brekke, J. S. (2014). The American Academy of Social Work and Social Welfare: History and grand challenges. Research on Social Work Practice, 24(4), 495-500. https://doi.org/10.1177/1049731514527801

Begun, A. L., Berger, L. K., Otto-Salaj, L. L., \& Rose, S. J. (2010). Developing effective social work university-community research collaborations. Social Work Research, 55(1), 54-62. https://doi.org/10.1093/sw/55.1.54

Brekke, J. S. (2012). Shaping a science of social work. Research on Social Work Practice, 22 (5), 455-464. https://doi.org/10.1177/1049731512441263

Brekke, J. S. (2013). A Science of social work, and social work as an integrative scientific discipline: Have we gone too far, or not far enough? Research on Social Work Practice, 24(5), 517-523. https://doi.org/10.1177/1049731513511994

Brekke, J. S., Ell, K., \& Palinkas, L. A. (2007). Translational science at the National Institute of Mental Health: Can social work take its right place? Research on Social Work Practice, 17, 1-11. https://doi.org/10.1177/1049731506293693 
Brunswick Heineman, M. (1981). The obsolete scientific imperative in social work research. Social Service Review, 55, 371-397. https://doi.org/10.1086/643939

Bureau of Labor Statistics, U.S. Department of Labor. (2010). Occupational outlook handbook, 2010-11 edition. Retrieved August 20, 2015, from http:/www.bls.gov/oco

Cheetham, J. (1997). Evaluating social work: Progress and prospects. Research on Social Work Practice, 7(3), 291-310. https://doi.org/10.1177/104973159700700301

Clancy, C. M., \& Cronin, K. (2005). Evidence-based decision making: Global evidence, local decisions. Health Affairs, 24(1), 151-162. https://doi.org/10.1377/hlthaff.24.1.151

Cook, L. J. (1994). The Soviet Social Contract and Why It Failed: Welfare Policy and Workers' Politics from Brezhnev to Yeltsin. US: Presidents and Fellow of Harvard College.

Coulton, C. (2005). The Place of community in social work practice research: Conceptual and methodological developments. Social Work Research, 29(2), 73-86. https://doi.org/10.1093/swr/29.2.73

Council of Europe. (1996). The Initial and Further Training of Social Workers Taking into Account their Changing Role (Strasbourg, Council o Europe).

Council on Social Work Education (CSWE). (2009). United states-based conceptualization of international social work education, by Richard J. Estes, Commission on Global Social Work Education, Alexandria VA, 47 (http://www.cswe.org/File.aspx?id=31429)

Currie, M., King, G, Rosenbaum, P., Law, M., Kertoy, M., \& Specht, J. (2005). A model of impacts of research partnerships in health and social services. Evaluation and Program Planning, 28, 400-412. https://doi.org/10.1016/j.evalprogplan.2005.07.004

Deligran, P., \& Hojer, S. (2000) Knowledge, Academisation and Professionalisation in Social Work (Goteborg, Kompendiet).

DePoy, E., Hartman, A., \& Haslet, D. (1999). Critical action research: A model for social work knowing. Social Work, 44(6), 560-569. https://doi.org/10.1093/sw/44.6.560

Dunn, S.P. and Dunn, E. (1989). Everyday Life of people with disabilities in the USSR. In W. O. McCagg, \& L. Siegelbaum (Eds). People with Disabilities in the Soviet Union: Past and Present, Theory and Practice. Pittsburgh: University of Pittsburgh Press.

Erath, P., \& Littlechild, B. (Eds.). (2010) Social work across Europe. Accounts from 16 countries. Ostrava: ERIS with Albert.

ESRC Report. (2000). Theorizing Social Work Research. Report of an ESRC-sponsored seminar series.

Federal Research Division of the Library of Congress. (1989). Soviet Union - A Country Study. Available online at: http://www.country-data.com/cgi-bin/query/r-12574.html

Fong, R. (2013). Framing doctoral education for a science of social work: Positioning students for scientific career, promoting scholars for the academy, propagating scientists of the profession, and preparing stewards of the discipline. Research on Social Work Practice, 24(5), 607-615. https://doi.org/10.1177/1049731513515055

Fong, R. (2012). Framing education for a science of social work: missions, curriculum, and doctoral training. Research on Social Work Practice, 22(5), 529-536. https://doi.org/10.1177/1049731512452977 
Friedenberg, D. S. (1987).Medicine in Perspective: Soviet health care system. The western Journal of Medicine, 147(2), 214-217.

Garvin, C. (2000). Doctoral research training: the American way. Paper presented to the ESRC Seminar 3, http://www.nisw.org.uk/tswr/garvin.html.

Guerrero, E. G. (2014). What does if take for social work to evolve to science status? Discussing definition, structure, and contextual challenges and opportunities. Research on Social Work Practice, 24(5), 601-606. https://doi.org/10.1177/1049731513511993

Harrington, D., Petr, C., Black, B., \& Cunningham-Williams, R. (2013). Quality guidelines for PhD programs in social work. GADE Taskforce on Quality Guidelines. Unpublished manuscript, Group for the Advancement of Doctoral Education in Social Work.

Howard, M. O. (2010). Improving the annual conference of the Society for Social Work Research. Social Work Research, 34(1), 3-5. https://doi.org/10.1093/swr/34.1.3

Howard, M. O. (2009). Reflections and the need for social work research. Social Work Research, 33(1), 3-4. https://doi.org/10.1093/swr/33.1.3

IFSW (2014, July). International Federation of Social Workers: Global Definition of Social Work, approved by the IFSW General Meeting and the IASSW General Assembly. Retrieved September 20, 2015, from http://ifsw.org/get-involved/global-definition-of-social-work/

IFSW. (2014). International Federation of Social Workers: Statement in support of Social Workers in South Caucasus Region. Retrieved December 27, 2015, from http://ifsw.org/wp content/uploads/2014/09/Statement-of-IFSW-Europe-in-Support-of-Social-Workers-in-South -Caucasus-Region.pdf

Jason, L. A., Pokorny, S. B., Ji, P., \& Kunz, C. (2005). Developing community-school-university partnerships to control youth access to tobacco. Journal of Educational and Psychological Consultation, 16, 201-222. https://doi.org/10.1207/s1532768xjepc1603_4

Jenson, J. M. (2006). A Call for Social Work Research from the National Institutes of Health. Social Work Research, 30(1), 3-5. https://doi.org/10.1093/swr/30.1.3

Jenson, J. M. (2008). Enhancing research capacity and knowledge development through Social work doctoral education. Social Work Research, 32(1), 3-5. https://doi.org/10.1093/swr/32.1.3 Jenson, J. M., Briar-Lawson, K., \& Flanzer, J. P. (2008). Advances and challenges in developing research capacity in social work. Social Work Research, 32(4), 197-200. https://doi.org/10.1093/swr/32.4.197

Laot, F. (2000). Doctoral work in the social work in Europe. Social Work in Europe, 7(2), 2-7. Longhofer J., \& Floersch, J. (2012). The coming crisis in social work: Some thoughts on social work and science. Research on Social Work Practice, 22(5), 499-519. https://doi.org/10.1177/1049731512445509

Lyons, K. (2010). Doctoral studies in social work: exploring European developments. The International Journal, 22(6), 555-564. http://dx.doi.org/10.1080/0261547032000142661

Madison, B. Q. (1968). Social Welfare in the Soviet Union. Stanford, Calif.: Stanford University Press.

Marsh, C. M. (2012). From fish and bicycles to a science of social work. Research on Social 
Work Practice, 22(5), 465-467. https://doi.org/10.1177/1049731512441837

Morrissey, E., Wandersman, A., Seybolt, D., Nation, M., Crusto, C., \& Davino, K. (1997). Toward a framework for bridging the gap between science and practice in prevention: A focus on evaluator and practitioner perspectives. Evaluation and Program Planning, 20, 367-377. https://doi.org/10.1016/S0149-7189(97)00016-5

Mullen, E. J. (2002). Evidence-based social work theory and practice: historical and reflective perspective. Paper presented at the 4th International Conference on Evaluation for Practice, University of Tampere, Finland, 4/6 July 2002.

National Advisory Mental Health Council. (1991). Building Social Work Knowledge for Effective Services and Policies. A Plan for Research Development. Washington, DC: NIMH. Available from IASWR, 750 First Street, NE, Suite 700, Washington DC $20002-4241$.

National Association of Social Workers. (2008). Code of ethics. Washington, DC: Author. Retrieved from https://www.socialworkers.org/pubs/code/default.asp

NASW - National Association of Social Workers. (2015). The Action Network for SocialWork Education and Research (ANSWER). Retrieved September 23 from NASW Web site http://www.naswdc.org/advocacy/answer/default.asp

Nurius, P., Brekke, J., \& Fong, R. (2010). Translational research: A new horizon for social work research. Paper presented at the annual conference of the Council of Social Work Education, Portland, OR.

O'Fallon, L. R., \& Dearry, A. (2002). Community-based participatory research as a tool to advance environmental health sciences. Environmental Health Perspectives, 110(Suppl. 2), 155-159. https://doi.org/10.1289/ehp.02110s2155

Payne, M. (2006). International social work research and health inequalities. Journal of Comparative Social Welfare, 22(2), 115-124. http://dx.doi.org/10.1080/17486830600836099

Payne, M. (2002). Social work theories and reflective practice. In R. Adams, L. Dominelli, \& M. Payne (Eds.), Social Work: Themes, Issues and Critical Debates (pp.123-139). Palgrave: Basingstoke.

Penna, S, Paylor, I., \& Washington, J. (2000). Globalization, social exclusion and the possibilities for global social work and welfare. European Journal of Social Work, 3(2), 109-122. http://dx.doi.org/10.1080/714052818

Plath, D. (2006). Evidence-Based Practice: Current issues and future directions. Australian Social Work, 59(1), 56-72. http://dx.doi.org/10.1080/03124070500449788

Proctor, E. K. (2003). Research to inform the development of social work interventions. Social Work Research, 27(1), 3-5. https://doi.org/10.1093/swr/27.1.3

Reid, J. R. (2001). The role of science in social work: The perennial debate. Journal of Social Work, 1(3), 273-293. https://doi.org/10.1177/146801730100100303

Rosen, A. (1996). The scientific practitioner revisited: Some obstacles and prerequisites for fuller implementation in practice. Research on Social Work Practice, 20, 105-111. https://doi.org/10.1093/swr/20.2.105

Shaw, I. (2014). A science of social work? Response to John Brekke. Research on Social Work Practice, 24(5), 524-526. https://doi.org/10.1177/1049731514543408 


\section{Macrothink}

International Journal of Social Work

ISSN 2332-7278 2017, Vol. 4, No. 1

Sommerfeld, P. (2014). Social work as an action science: A perspective from Europe. Research on Social Work Practice, 24, 586-600. https://doi.org/10.1177/1049731514538523

Strier, R. (2007). Anti-oppressive research in social work: A preliminary definition. British Journal of Social Work, 37 (5), 857-871. https://doi.org/10.1093/bjsw/bc1062

Tobis, D. (2000). Moving from Residential Institutions to Community-Based Social Services in Central and Eastern Europe and the Former Soviet Union. Washington D.C.: World Bank. https://doi.org/10.1596/0-8213-4490-0

Tripodi, T. \& Potocky-Tripodi, M. A Typology of international social work research. Journal of Social Work Research and Evaluation, 6(1), 3-4.

Unick, G. J., \& Stone, S. (2010). State of modern measurement approaches in social work research literature. Social Work Research, 34(2), 94-101. https://doi.org/10.1093/swr/34.2.94

Viswanathan, M., Ammerman.A., Eng, E., Gartlehner, G, Lohr, K. N, \& Griffith, D. (2004). Community based participatory research: Assessing the evidence [Evidence Report/Technology Assessment No. 99 AHRQ Publication 04-E022-2]. Rockville, MD: Agency for Healthcare Research and Quality.

Webb, S. (2002). Evidence-based practice and decision analysis in social work: An implementation model, Journal of Social Work, 2(1), 45-63. https://doi.org/10.1177/146801730200200104

Whitaker, T., Weissmuller, T., \& Clark, E. (2006). Assuring the sufficiency of a frontline workforce: A national study of licensed social workers. Executive summary. Washington, DC: National Association of Social Worker. Retrieved from http://workforce.socialworkers.org/studies/natstudy.asp

Witkin, S. L. (1995). Whither social work research? An essay review. Social Work, 40(3), 424-428.

\section{Copyright Disclaimer}

Copyright reserved by the author(s).

This article is an open-access article distributed under the terms and conditions of the Creative Commons Attribution license (http://creativecommons.org/licenses/by/3.0/). 